Contents list available at Multidisciplinary Journal website Multidisciplinary Journal

Journal homepage: https://jurnal.unej.ac.id/index.php/multijournal

\title{
Pengaruh Indikator Perilaku Hidup Bersih dan Sehat (PHBS) Terhadap Gejala Pneumonia Pada Balita di Puskesmas Mojopanggung (perkotaan), Puskesmas Tapanrejo (pedesaan) dan Puskesmas Kedungrejo (pesisir) Banyuwangi
}

\author{
The Effect of Healthy and Clean Living Behaviour (HCLB) on Pneumonia Symptoms in Toddlers in \\ Mojopanggung Community Health Centre (City), Tapanrejo Health Centre (village) and Kedungrejo \\ Community Health Centre (coastal area) of Banyuwangi
}

\author{
Dyah Ayu ${ }^{1}$, Sugeng Winarso ${ }^{2}$, Dewi Rokhmah ${ }^{3}$ \\ 1Prodi Pascasarjana Ilmu Kesehatan Masyarakat Universitas Jember \\ 2Prodi Pascasarjana Ilmu Kesehatan Masyarakat Univeristas Jember \\ 3 Fakultas Kesehatan Masyarakat Universitas Jember \\ Email Penulis Koresponden: winarsosugeng@gmail.com
}

\begin{abstract}
ABSTRAK. Program PHBS dalam rumah tangga merupakan usaha untuk memberikan pengetahuan pada anggota keluarga agar dapat mempraktekkan perilaku yang bersih, sehat dan ikut serta dalam kesehatan di lingkungan masyarakat. Tujuan mengaplikasikan PHBS dalam rumah tangga adalah supaya anggota keluarga menjadi sehat. Tingkat kesehatan seseorang, keluarga, masyarakat serta lingkungan berkaitan dengan PHBS. Dalam tatanan rumah tangga 10 indikator PHBS harus dipraktekkan oleh anggota rumah tangga. PHBS harus diawali dari rumah tangga, hal ini dikarenakan rumah tangga yang sehat menjadi aset pembangunan yang kesehatannya harus dijaga. Tujuan penelitian ini adalah menganalisis pengaruh PHBS terhadap gejala pneumonia pada balita di Puskesmas Mojopanggung (perkotaan), Puskesmas Tapanrejo (pedesaan) dan Puskesmas Kedungrejo (pesisir) Banyuwangi. Jenis penelitian ini deskriptif analitik dengan pendekatan case control dan menggunakan analisa data regresi ordinal dengan populasi 8.883 responden, sampel yang digunakan adalah simple random sampling berjumlah 104 responden. Hasil penelitian menunjukkan bahwa terdapat pengaruh antara Pengaruh Perilaku Hidup Bersih dan Sehat (PHBS) terhadap gejala pneumonia pada balita dengan nilai signifikan pada wilayah kerja Puskesmas Mojopanggung 0,001, Puskesmas Tapanrejo dengan nilai signifikan 0,0026 dan Puskesmas Kedungrejo dengan nilai signifikan 0,0029.
\end{abstract}

Kata Kunci: Perilaku Hidup Bersih dan Sehat (PHBS), Pneumonia, Balita .

ABSTRACT. HCLB Program for the households is an attempt to provide knowledge for the family members to practice clean, health living behavior and to participate in the health of community environment. HCLB purpose is the health of the family members. The health level of individuals, family, community and environment is related HCLB. In the household level, there are 10 HCLB indicators to be practiced by the family members. HCLB should be started from the household since its health, considered as the asset of development, should be taken care of. This research aims to analyze the effect of HCLB program on pneumonia symptom in toddlers in Mojopanggung Community Health Centre (citiy), Tapanrejo Community Health Centre (village), Kedungrejo Community Health Centre (coastal area) of Banyuwangi. This research applies analytic descriptive using case control approach and ordinal regression data analysis with the population of 8,883 respondents. The sample includes simple random sampling of 104 respondents. The findings shows that there is an effect of HCLB Program on Penumonia symptoms on toddlers with significant value of 0,001 in Mojopanggung Community Health Centre, of 0,0026 in Tapanrejo Community Health Centre and of 0,0029.in Kedungrejo Community health centre.

Key words: Healthy and Clean Living Behaviour (HCLB), Pneumonia, Toddlers.

\section{Pendahuluan}

Program PHBS dalam rumah tangga merupakan usaha untuk memberikan pengetahuan pada anggota keluarga agar dapat mempraktekkan perilaku yang bersih, sehat dan ikut serta dalam kesehatan di lingkungan masyarakat. Tujuan mengaplikasikan PHBS dalam rumah tangga adalah supaya anggota keluarga menjadi sehat. Tingkat kesehatan 
seseorang, keluarga, masyarakat serta lingkungan berkaitan dengan PHBS[2]. Dalam tatanan rumah tangga 10 indikator PHBS harus dipraktekkan oleh anggota rumah tangga. PHBS harus diawali dari rumah tangga, hal ini dikarenakan rumah tangga yang sehat menjadi aset pembangunan yang kesehatannya harus dijaga.

Tujuan PHBS dipraktekkan oleh anggota keluarga adalah untuk mencegah adanya penyakit infeksi ataupun penyakit tidak menular. PHBS menjadi tindakan yang tepat untuk mencegah penyakit. Hal ini dikatakan juga bahwa PHBS menjadi penentu penyakit serta pencegahannya[1]. Pencegahan penyakit yang dapat dicegah adalah penyakit yang diakibatkan oleh kuman, infeksi menular, jantung, paru - paru, hipertensi, obesitas dan lainya[6].

Program pembinaan PHBS yang dikeluarkan pemerintah sudah berjalan cukup lama, namun pencapaian masih jauh dari target. Target pencapaian rumah tangga sehat di Kabupaten Banyuwangi tahun 2018 adalah sebesar $69 \%$. Salah satu upaya untuk dilakukan untuk mengetahui pencapaian rumah tangga sehat yaitu dengan survey Kartu Kesehatan Kaluarga (K3) didapatkan capaian rumah tangga yang berperilaku hidup bersih dan sehat pada tahun 2016 49,28\% dari 163.598 dari jumlah rumah tangga, pada tahun 2017 46,59\% dari 126.223 dari jumlah rumah tangga dan mengalami penurunan pada tahun $2018 \quad 42,09 \%$ dari 116.325 dari jumlah rumah tangga. Dari data tersebut dapat ditarik kesimpulan bahwa rumah tangga yang menerapkan Perilaku Hidup Bersih dan Sehat (PHBS) di Kabupaten Banyuwangi mengalami penurunan setiap tahunnya [5].

Penemuan kasus balita menderita pneumonia di Kabupaten Banyuwangi pada tahun 2016 didapatkan 2.948 balita menderita pneumonia, pada tahun 2017 didapatkan 3.498 balita menderita pneumonia dan meningkat pada tahun 2018 didapatkan 3.566 balita yang menderita pneumonia. Tiga wilayah kerja puskesmas di Kabupaten Banyuwangi yang memiliki angka kejadian pneumonia pada balita tertinggi merupakan Puskesmas Mojopanggung yang mewakili wilayah puskesmas perkotaan dengan penemuan 133 kasus balita menderita pneumonia, Puskesmas Kedungrejo yang mewakili wilayah puskesmas pesisir dengan penemuan 168 kasus balita menderita pneumonia dan Puskesmas Tapanrejo yang mewakili wilayah pedesaan dengan penemuan 101 kasus balita menderita pneumonia [6].

Anak yang menderita pneumonia disebabkan oleh berkurangnya mengembangnya fungsi paru, sehingga menimbulkan anak anak menjadi bernafas cepat untuk menghindari timbulnya hipoksia. Gejala jika pneumonia menjadi parah apabila ditandai dengan paru - paru menjadi kaku serta dinding dada bagian bawah tertarik ke dalam. Hipoksia dan sepsis yang diakibatkan pneumonia pada anak dapat menyebabkan kematian, hal ini dikarenakan sel - sel yang tidak bekerja disebabkan paru yang berkurang kemampuan menyerap oksigen. Balita sangat rentang dengan ISPA yang dapat meningkat menjadi pneumonia. Karena itulah, apabila balita yang menderita ISPA harus segera mendapat penanganan untuk mencegah terjadinya pneumonia[7].

\section{Bahan dan Metode}

Penelitian ini merupakan penelitian kuantitatif dengan metode penelitian deskriptif analitik dan analisa data menggunakan regresi ordinal yang bertujuan untuk mengetahui pengaruh PHBS terhadap gejala pneumonia pada balita. Penelitian ini menggunakan pengumpulan data secara kasus kontrol (case control) yang dilakukan dengan membandingkan kelompok kasus dan kelompok kontrol. Kelompok kasusnya adalah balita yang menderita pneumonia di wilayah kerja Puskesmas Mojopanggung, Puskesmas Tapanrejo dan Puskesmas Kedungrejo dan kelompok kontrol dalam penelitian ini adalah balita yang tidak menderita pneumonia yang berada di sekitar rumah balita yang menderita pneumonia di wilayah kerja Puskesmas Mojopanggung, Puskesmas Tapanrejo dan Puskesmas Kedungrejo Banyuwangi.

Populasi dalam penelitian ini berjumlah 8.883 orang yang terdiri dari balita yang di diagnose pneumonia untuk kelompok kasus dan balita yang tidak di diagnose untuk kelompok kontrol yang tinggal di wilayah kerja Puskesmas Mojopanggung, Puskesmas Tapanrejo dan Psukesmas Kedungrejo Banyuwangi. Sampel dalam penelitian ini berjumlah 104 responden yang dibagi menjadi dua kelompok yaitu 52 responden kelompok kasus yang terdiri dari balita yang di diagnose pneumonia dan 52 responden kelompok kontrol yang terdiri dari balita yang tidak di diagnose pneumonia di wilayah kerja Puskesmas Mojopanggung, Puskesmas Tapanrejo dan Puskesmas Kedungrejo Banyuwangi.

Analisis dalam penelitian ini adalah analisis deskriptif dan analisis regresi ordinal. Analisis deskriptif digunakan untuk menggambarkan secara umum mengenai karakteristik responden yang mempunyai balita di diagnose pneumonia dan responden yang mempunyai balita tidak di diagnose pneumonia. Sementara itu, analisis regresi ordinal digunakan untuk menguji Pengaruh PHBS terhadap gejala pneumonia pada balita.

\section{Hasil dan Pembahasan}

Hasil penelitian dibawah ini memaparkan tentang indikator PHBS tatanan rumah tangga yang terdiri dari persalinan ditolong tenaga kesehata, ASI ekslusif, setiap bulan timbang berat badan bayi dan balita, setiap hari mengkonsumsi buah dan sayur serta tidak merokok didalam rumah di wilayah kerja Puskesmas Mojopanggung, Puskesmas Kedungrejo dan Puskesmas Tapanrejo.

Tabel 3.1 Gambaran indikator persalinan nakes

\begin{tabular}{lll}
\hline Persalinan nakes & Jumlah & $\%$ \\
\hline $\begin{array}{l}\text { Puskesmas } \\
\text { Mojopanggung }\end{array}$ & 36 & 100 \\
\hline $\begin{array}{l}\text { Puskesmas } \\
\text { Kedungrejo }\end{array}$ & 39 & 97,5 \\
\hline $\begin{array}{l}\text { Puskesmas } \\
\text { Tapanrejo }\end{array}$ & 27 & 96,4 \\
\hline
\end{tabular}


Tabel 3.1 menunjukkan gambaran indikator persalinan ditolong tenaga kesehatan dalam kategori baik di wilayah kerja Puskesmas Mojopanggung sebanyak 100\% atau seluruh ibu hamil melahirkan ditolong tenaga kesehatan, Puskesmas Tapanrejo sebanyak 96,4\% hampir seluruh ibu hamil melahirkan ditolong tenaga kesehatan dan Puskesmas Kedungrejo sebanyak 97,5\% atau hampir seluruh ibu hamil melahirkan ditolong tenaga kesehatan.

Ibu hamil yang persalinannya ditolong oleh dokter maupun bidan akan lebih aman bagi keselamatan ibu serta bayi, hal ini dikarenakan didampingi oleh tenaga ahli serta menggunakan menggunakan alat yang steril sehingga dapat mencegah infeksi dan penyakit. Selain itu, dengan melahirkan pada petugas kesehatan dapat mendeteksi awal apabila ditemukan kelainan selama proses persalinan sehingga dapat segera dirujuk pada puskesmas maupun rumah sakit [4].

Tabel 3.2 Gambaran indikator ASI ekslusif

\begin{tabular}{lll}
\hline ASI ekslusif & Jumlah & $\%$ \\
\hline $\begin{array}{l}\text { Puskesmas } \\
\text { Mojopanggung }\end{array}$ & 6 & 16,7 \\
\hline $\begin{array}{l}\text { Puskesmas } \\
\text { Kedungrejo }\end{array}$ & 6 & 15 \\
\hline $\begin{array}{l}\text { Puskesmas } \\
\text { Tapanrejo }\end{array}$ & 5 & 17,8 \\
\hline
\end{tabular}

Tabel 3.2 menunjukkan gambaran indikator ASI ekslusif di Puskesmas Mojopanggung paling banyak 16,7\% bayi yang mendapat ASI ekslusif, Puskesmas Tapanrejo paling banyak $15 \%$ bayi yang mendapat ASI ekslusif dan Puskesmas Kedungrejo paling banyak 17,8\% bayi yang mendapat ASI ekslusif. Memberikan ASI tanpa makan dan minuman padai bayi yang berusia 0 hari sampi 6 bulan memiliki manfaat yang baik, karena ASI mengandung kekebalan tubuh yang sangat baik untuk tumbuh kembang bayi [4].

Tabel 3.3 Gambaran indikator setiap bulan menimbang

\begin{tabular}{llc} 
Menimbang & Jumlah & $\%$ \\
\hline $\begin{array}{l}\text { Puskesmas } \\
\text { Mojopanggung }\end{array}$ & 27 & 75 \\
\hline $\begin{array}{l}\text { Puskesmas } \\
\text { Kedungrejo }\end{array}$ & 23 & 57,5 \\
\hline $\begin{array}{l}\text { Puskesmas } \\
\text { Tapanrejo }\end{array}$ & 5 & 50 \\
\hline
\end{tabular}

Tabel 3.3 menunjukkan gambaran indikator setiap bulan menimbang berat badan bayi dan balita di Puskesmas Mojopanggung sebagian besar $75 \%$ setiap bulan bayi dan balita timbang berat badan, Puskesmas Tapanrejo sebagian $50 \%$ setiap bulan bayi dan balita timbang berat badan dan Puskesmas Kedungrejo sebagian besar $57,5 \%$ setiap bulan bayi dan balita timbang berat badan. Setiap bulan datang ke posyandu untuk menimbang bayi dan balita dari umur 1 bulan sampai dengan 5 tahun bertujuan untuk memantau tumbuh kembang bayi dan balita. Selain itu, menimbang di posyandu memiliki manfaat untuk mengetahui status imunisasi dan konsultasi gizi bayi dan balita agar dapat tumbuh sehat[4].
Tabel 3.4 Gambaran indikator setiap hari konsumsi buah dan sayur

\begin{tabular}{lll}
\hline Menimbang & Jumlah & $\%$ \\
\hline $\begin{array}{l}\text { Puskesmas } \\
\text { Mojopanggung }\end{array}$ & 19 & 52,8 \\
\hline $\begin{array}{l}\text { Puskesmas } \\
\text { Kedungrejo }\end{array}$ & 15 & 37,5 \\
\hline $\begin{array}{l}\text { Puskesmas } \\
\text { Tapanrejo }\end{array}$ & 16 & 57,1 \\
\hline
\end{tabular}

Tabel 3.4 menunjukkan gambaran indikator setiap konsumsi buah dan sayur di Puskesmas Mojopanggung sebagian besar 52,8\% setiap hari diberikan buah dan sayur, Puskesmas Tapanrejo sebagian 57,1\% setiap hari diberikan buah dan sayur dan Puskesmas Kedungrejo paling banyak $37,5 \%$ setiap hari diberikan buah dan sayur. Sebagai sumber vitamin, mineral dan serat untuk tubuh makan perlu mengkonsumsi buah dan sayur agar dapat memenuhi gizi yang seimbang[1]. Agar dapat memenuhi gizi yang seimbang maka anggota keluarga disarankan untuk selalu konsumsi 3 porsi buah dan 2 porsi sayur[4].

Tabel 3.5 Gambaran indikator tidak merokok dalam rumah

\begin{tabular}{lll} 
Menimbang & Jumlah & $\%$ \\
\hline $\begin{array}{l}\text { Puskesmas } \\
\text { Mojopanggung }\end{array}$ & 11 & 30,6 \\
\hline $\begin{array}{l}\text { Puskesmas } \\
\text { Kedungrejo }\end{array}$ & 7 & 17,5 \\
\hline $\begin{array}{l}\text { Puskesmas } \\
\text { Tapanrejo }\end{array}$ & 4 & 14,3 \\
\hline
\end{tabular}

Tabel 3.5 menunjukkan gambaran indikator tidak merokok dalam rumah di Puskesmas Mojopanggung paling banyak $30,6 \%$ tidak ada anggota keluarga yang merokok dalam rumah, Puskesmas Tapanrejo paling banyak 14,3 tidak ada anggota keluarga yang merokok dalam rumah dan Puskesmas Kedungrejo paling banyak 17,5 tidak ada anggota keluarga yang merokok dalam rumah. Anggota keluarga yang merokok dalam rumah dapat menjadi faktor yang dapat menyebabkan masalah kesehatan dalam keluarga khususnya pada balita yang rentang terhadap penyakit ISPA[9].

Tabel 3.6 Gambaran distribusi balita pneumonia

\begin{tabular}{lll}
\hline Puskesmas & Jumlah & $\%$ \\
\hline Mojopanggung & 17 & 47,2 \\
\hline Kedungrejo & 22 & 55 \\
\hline Tapanrejo & 13 & 46,4 \\
\hline
\end{tabular}




\section{Gambaran distribusi} balita pneumonia

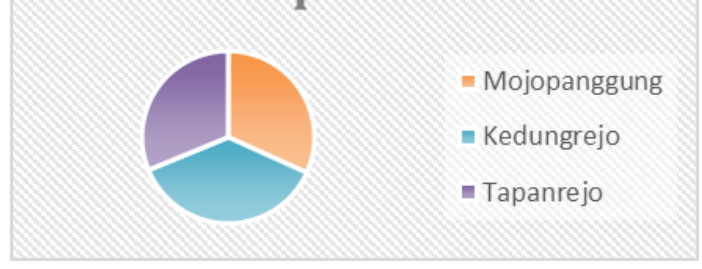

Tabel 3.6 menunjukkan gambaran distribusi balita pneumonia di Puskesmas Mojopanggung paling banyak 47,2\%, Puskesmas Tapanrejo paling banyak 46,4\% dan Puskesmas Kedungrejo sebagian besar 55\%. Pneumonia menjadi salah satu penyakit infeksi yang menyerang saluran pernafasan yang disebakan oleh virus, bakteri aupun jamur dengan gejala batuk dan radang pada paru paru. Balita sangat rentang dengan penyakit pernafasan dikarenakan system fisiologis pada balita belum matur sehingga pada masa pertumbuhan dan perkembangan ini balita perlu dijaga kesehatannya untuk mengurangi tingginya angka mordibitas dan mortalitas balita yang berusia dibawah 5 tahun[10].

\begin{tabular}{lllll}
\multicolumn{4}{c}{ Tabel 3.7 Pengaruh PHBS dengan pneumonia } \\
\hline No & Puskesmas & sig. & 95 CI & \\
\cline { 3 - 5 } & & & $\begin{array}{l}\text { Lower } \\
\text { Bound }\end{array}$ & Upper \\
& & & Bound \\
\hline 1 & Mojopanggung & $0,001^{*}$ & $-4,950$ & 1,358 \\
2. & Tapanrejo & $0,026^{*}$ & $-0,718$ & 1,579 \\
3. & Kedungrejo & $0,029^{*}$ & -0579 & 2,936 \\
\hline
\end{tabular}

Tabel 3.7 menjelaskan hasil uji regresi ordinal didapatkan nilai signifikan pada wilayah Puskesmas Mojopanggung didapatkan 0,001 artinya terdapat pengaruh PHBS dengan pneumonia pada balita. Pada wilayah kerja Puskesmas Tapanrejo didapatkan hasil signifikan 0,026 artinya terdapat pengaruh PHBS terhadap pneumonia pada balita. Sedangkan pada wilayah kerja Puskesmas Kedungrejo didapatkan hasil nilai signifikan 0,029 artinya terdapat pengaruh PHBS terhadap pneumonia pada balita.

Hasil analisis di wilayah kerja Puskesmas Mojopanggung (perkotaan) menunjukkan hipotesis di terima, artinya terdapat pengaruh PHBS terhadap gejala pneumonia pada balita. Hal ini dikarenakan rendahnya ibu balita yang memberikan ASI ekslusif. Pemberian susu formula menjadi salah satu penyebab ibu tidak memberikan ASI ekslusif kepada bayinya. Ibu beralasan memberikan susu formula kepada bayinya karena setelah melahirkan ASI tidak langsung keluar dan bayi terus menangis sehingga ibu memberikan susu formula. Memberikan susu formula tidak dapat memenuhi nutrisi yang terdapat pada ASI. Susu formula mengandung gizi yang kurang untuk balita dan pencernaan bayi sulit menyerapnya. Susu formula juga tidak mengandung anti bodi sehingga dapat menyebabkan alegri pada bayi. Bayi yang tidak mendapat ASI ekslusif lebih besar kemungkinan terkena ISPA dibandingkan dengan bayi mendapat ASI ekslusif.
Penelitian ini sejalan dengan penelitian yang dilakukan oleh Elizabeth bahwa terdapat hubungan menyusui ekslusif dengan pneumonia pada balita, meyusui tidak eskslusif selama 6 bulan akan menyebabkan keparahan defisiensi berhubungan dengan keparahan pneumonia yang merupakan peyakit pembunuh utama pada anak - anak.

Hasil analisis di wilayah kerja Puskesmas Kedungrejo (pesisir) menunjukkan hipotesis di terima, artinya terdapat pengaruh PHBS terhadap gejala pneumonia pada balita. Dikarenakan rendahnya ibu balita yang memberikan ASI ekslusif dan tidak merokok dalam rumah. Ibu beralasan memberikan susu formula karena produksi ASI yang kurang dan ada ibu yang memberikan makanan dan minuman selain ASI sebelum usia dari 6 bulan, misalnya memberikan madu atau kelapa muda pada bayi. Pengenalan makanan yang tidak disarankan terlalu dini kepada bayi dapat meingkatkan resiko alergi karena sistem percenaan bayi masih rentan. Penelitian ini sejalan dengan Armina berdasarkan hasil penelitian yang berperan dalam hubungan kejadian pneumonia pada balita [1]. Pemberian nutrisi bagi bayi selain ASI, misalnya pisang Maupin air putih dapat lebih beresiko terkena infeksi. Terlalu cepat memberikan makanan selain ASI dapat berakibat berkurangnya kebutuhan ASI pada bayi sehingga kekebalan terhadap infeksi dapat berkurang. Pada rendahnya indikator tidak merokok di dalam rumah karena merokok menjadi gaya hidup masyarakat pesisir, kepala keluarga atau anggota keluarga yang merokok beralasan untuk menghilangkan rasa capek sepulang dari mencari ikan di laut. Anggota keluarga serumah yang biasa merokok adalah salah satu faktor yang dapat memperbesar resiko untuk menderita gangguan pernafasan. Bayi yang terpapar asap rokok dapat membahayakan tubuhnya, hal ini dikarenakan organ tubuh bayi masih belum matur. Jika bayi terpapar dengan asap rokok beresiko lebih besar daripada perokk itu sendiri, hal ini dikarenakan asap rokok tersebut sangat beracun. Penelitian ini sejalan dengan Zhuge bahwa terdapat hubungan balita yang terpapar asap rokok di lingkungan rumah tangga akan memperparah pneumonia pada bayi. Paparan asap tembakau pada lingkungan meadi sumber uatama partikel halus yang tehirup di dalam ruangan. Orangtua yang merokok berkontribusi pada resiko pneumonia pada anak di bawah usia 5 tahun [6].

Hasil analisis di wilayah kerja Puskesmas Tapanrejo (pedesaan) menunjukkan hipotesis di terima, artinya terdapat pengaruh PHBS terhadap gejala pneumonia pada balita. Hal ini dikarenakan rendahnya ibu balita yang memberikan ASI ekslusif dan tidak merokok di dalam rumah. Ibu beralasan memberikan makan maupun minum selain ASI sejak sebelum usia 6 bulan, misalnya diberikan pisang atau nasi dicampur ASI pada bayi. Pengenalan makanan yang tidak disarankan terlalu dini kepada bayi dapat meingkatkan resiko alergi karena sistem percenaan bayi masih rentan. Penelitian ini sejalan dengan Armina berdasarkan hasil penelitian yang berperan dalam hubungan kejadian pneumonia pada balita [1]. Pemberian nutrisi bagi bayi selain ASI, misalnya pisang Maupin air putih dapat lebih beresiko terkena infeksi. Terlalu cepat memberikan makanan selain ASI dapat berakibat berkurangnya 
kebutuhan ASI pada bayi sehingga kekebalan terhadap infeksi dapat berkurang. Pada rendahnya indikator tidak merokok di dalam rumah karena merokok menjadi gaya hidup masyarakat pesisir, kepala keluarga atau anggota keluarga yang merokok beralasan untuk menghilangkan rasa capek atau untuk sekedar bersantai. Anggota keluarga serumah yang biasa merokok adalah salah satu faktor yang dapat memperbesar resiko untuk menderita gangguan pernafasan. Bayi yang terpapar asap rokok dapat membahayakan tubuhnya, hal ini dikarenakan organ tubuh bayi masih belum matur. Jika bayi terpapar dengan asap rokok beresiko lebih besar daripada perokk itu sendiri, hal ini dikarenakan asap rokok tersebut sangat beracun. Penelitian ini sejalan dengan Zhuge bahwa terdapat hubungan balita yang terpapar asap rokok di lingkungan rumah tangga akan memperparah pneumonia pada bayi. Paparan asap tembakau pada lingkungan meadi sumber uatama partikel halus yang tehirup di dalam ruangan. Orangtua yang merokok berkontribusi pada resiko pneumonia pada anak di bawah usia 5 tahun [6].

\section{Kesimpulan}

Berdasarkan hasil dari penelitian diatas dapat disimpulkan sebagai berikut:

1. Capaian rumah tangga sehat pada wilayah kerja Puskesmas Mojopanggung (pekrotaan), Puskesmas Tapanrejo (pedesaan) dan Puskesmas Kedungrejo (pesisir) masih dibawah target program PHBS.

2. Pada wilayah kerja Puskesmas Mojopanggung adalah indikator PHBS yang paling rendah adalah indikator ASI ekslusif.

3. Pada wilayah kerja Puskesmas Tapanrejo indikator PHBS yang paling rendah adalah indikator ASI ekslusif tidak merokok dalam rumah.

4. Pada Puskesmas Kedungrejo indikator PHBS yang paling rendah adalah ASI ekslusif dan tidak merokok di dalam rumah.

\section{Ucapan Terimakasih}

Terimakasih kepada Wilayah Kerja Puskesmas Mojopanggung, Puskesmas Tapanrejo dan Puskemas Kedungrejo Banyuwangi yang telah memberikan kesempatan untuk melakukan penelitian.

\section{Acuan Referensi}

[1] Aditianti, Hermina. 2016. Pengetahuan, sikap dan perilaku individu tentang makanan beraneka ragam sebagai salah satu indikator Keluarga Sadar Gizi (KADARZI). Bulletin penelitian kesehatan, Vol 44, No. 2, Juni 2016 : 117 - 126

[2] Armina, Arnati Wulansari. 2020. Korelasi Faktor Yang Berhubungan Dengan Kejadian Pneumonia Balita di Dua Puskesmas Kota Jambi. Jurnal Ilmiah Universitas Batanghari Jambi, vol. 20(1).

[3] Ayu, Heru. 2016. Gambaran Perilaku Hidup Bersih dan Sehat (PHBS) di Wilayah Kerja Puskesmas Bulu Kabupaten Sukoharjo Bulan Januari - Maret 2015. Jurnal Kesehatan, vol.1(1).

[4] Depkes RI. Perilaku Hidup Bersih dan Sehat. Jakarta: Depkes RI.

[5] Dinas Kesehatan Kabupaten Banyuwangi. 2017. Profil Kesehan Kabupaten Banyuwangi Tahun 2017. Banyuwangi: Dinkes Banyuwangi.

[6] Layya, Imran, \& Nasaruddin. 2016. Perilaku Hidup Bersih dan Sehat (PHBS) Dalam Tatanan Rumah Tangga Berbasis Kerusakan
Akibat Tsunami di Wilayah Kota Banda Aceh. Jurnal Ilmu Kebencanaan (JIKA), vol. 3(1).

[7] Merlinda, Widya. 2019. Tren Pneumonia Balita di Kota Semarang Tahun 2012-2018. Journal Of Public Health.

[8] Yang Zhuge, Hua Qian, Xiaohong Zheng. 2018. Residetial Risk Factors For Childhood Pneumonia: A Cross-sectional Study in Eight Cities Of China. Evironment International, 116, 83-01.

[9] Wardani, Winarsih, S., Sukini. T. 2015. Hubungan antara paparan asap rokok dengan kejadian Infeksi Saluran Pernafasan Bawah Akut (ISPA) pada balita di Desa Pucung Rejo Kabupaten Magelang. Jurnal Kebidanan ISSN: 2089 - 7669, Vol. 4, No. 8.

[10] Yuliana, I,. Shifa, M,. 2016. Hubungan status gizi dengan ketahanan terhadap ISPA non-pneumonia pada balita di Puskesmas Pekauman Banjarmasin. Jurnal Berkala Kedokteran. Vol.12, No.2, Sep-2016: 263-270. 